\title{
Superiority of simplified assay for folate with Lactobacillus casei ATCC 7469 over assay with chloramphenicol-adapted strain
}

\author{
BERNARD A. COOPER with the technical assistance of ERIKA JONAS \\ From the Haematology Division, Royal Victoria Hospital, and McGill University Medical Clinic, \\ Montreal, Quebec, Canada
}

SYNOPSIS Direct assay of serum folate by mixing serum with a mixture of $L$. casei and medium without autoclaving was found to provide serum folate results similar to those by extraction of serum with heat. This procedure was found more reliable than that using the same technique with chloramphenicol and a strain of $L$. casei adapted to grow in this material. A portion of apparent folate activity assayed in haemolysates by such direct assay was found to be due to material other than folate. It is recommended that heat extraction of haemolysates be continued for determination of whole blood folate, or that an additional standardization of technique be included if direct assay is used.

Microbiological assay of serum and whole blood folate with Lactobacillus casei is the standard basis of investigation of folate sufficiency in man, although other techniques for the determination of folate (Waxman, Schreiber, and Herbert, 1971; Rothenberg, Da Costa, and Rosenberg, 1972; Kamen and Hines, 1973) and to assess folate metabolism have been described. The technique of microbiological assay has been simplified by adaptation of a strain of $L$. casei to grow in chloramphenicol (Davis, Nicol, and Kelly, 1970; Millbank, Davis, Rawlins, and Waters, 1970). Several reports describing experience with this technique have appeared (Chanarin, Kyle, and Stacey, 1972; O'Broin, Scott, and Temperley, 1973). We have compared assay of serum and whole blood folate with this strain with that with the routine strain of $L$. casei. We have attempted to utilize the routine strain of $L$. case $i$ in a simplified assay technique based on the modifications of a technique developed for the chloramphenicolresistant organism, and have found it more reliable and convenient than the resistant strain. We have, in addition, compared the assay of whole blood folate by adding haemolysate directly to the assay medium and organism, with assay after precipitation of proteins by autoclaving.

Received for publication 22 August 1973.

\section{Materials and Methods}

MICROBIOLOGICAL ASSAY

Microbiological assay was conducted on samples of blood from inpatients and outpatients suspected of deficiency of folate or vitamin $B_{12}$. The assay utilized a commercial mix of medium (Baltimore Biologicals Folic Acid Assay PGA Broth, batch number 110679) and maintenance medium described previously (Baker, Herbert, Frank, Pasher, Hutner, Wasserman, and Sobotka, 1959). The assay organisms were Lactobacillus casei, ATCC 7469, and a strain adapted to $300 \mu \mathrm{g} / \mathrm{ml}$ of chloramphenicol (National Collection of Industrial Bacteria, Aberdeen). The latter was maintained in maintenance medium containing $300 \mu \mathrm{g} / \mathrm{ml}$ of chloramphenicol by subculture twice weekly. The routine $L$. case $i$ was maintained by weekly subculture.

\section{HEAT EXTRACTION METHOD}

Serum collected and stored for up to two weeks without added ascorbate was diluted 1:10 in 0.2 M phosphate at $\mathrm{pH} 6 \cdot 1$ containing $150 \mathrm{mg} \%$ of freshly dissolved ascorbic acid. The diluted serum was autoclaved at $1 \mathrm{~A}$ for one and a half $\mathrm{min}$ in a jacketed autoclave. The total time between placing the specimens into the autoclave and removing them was four minutes. The specimens were cooled, and $1 \mathrm{ml}$ 
was transferred to assay tubes $(20 \times 150 \mathrm{~mm}$ Pyrex) to which $9 \mathrm{ml}$ of a mixture of assay medium and assay organism was added with a pipetting machine (Brewer automatic pipetting machine). Specimens were incubated at $37^{\circ} \mathrm{C}$ for 18 hours in triplicate, and the optical density of growth was determined in a colorimeter equipped with a flow cell.

Frozen aliquots of whole blood were thawed on the bench, and $0.5 \mathrm{ml}$ was mixed with $9.5 \mathrm{ml}$ of $1 \mathrm{~g} \%$ of ascorbic acid in water. One $\mathrm{ml}$ of this was then transferred to the ascorbate buffer as for serum and assayed as described above.

\section{DIRECT ASSAY WITHOUT EXTRACTION}

One tenth $\mathrm{ml}$ of serum was added to assay tubes, and $9.9 \mathrm{ml}$ of a mixture of assay medium and organism was added with the pipetting machine. The remainder of the assay procedure was as described above. Whole blood was diluted 1:20 in $1 \mathrm{~g} \%$ ascorbate-water, and $\mathbf{0} \cdot 1 \mathrm{ml}$ of this haemolysate was transferred to assay tubes to which $9.9 \mathrm{ml}$ of assay medium and organism was added. Uninoculated blank tubes containing sample and medium but no organism were not used during routine assay.

\section{Preparation of the mixture of assay medium and organism}

Two thousand $\mathrm{ml}$ of single strength assay medium was mixed without autoclaving with $1 \mathrm{ml}$ of a sixhour culture of assay organism in maintenance medium and pipetted into assay tubes containing the prepared specimen. For direct assay, ascorbic acid, $150 \mathrm{mg} \%$, was incorporated into the assay medium, and for the $L$. casei adapted to chloramphenicol, $10 \mu \mathrm{g}$ per $\mathrm{ml}$ of chloramphenicol was present also. Ascorbate was not added to the medium when the assay technique included a dilution step in ascorbatebuffer, but was added to the tubes of the standard curve.

\section{Reading the assay}

After incubation for 18 hours at $37^{\circ} \mathrm{C}$, the optical density of the standards was determined in a Spectronic 20 colorimeter equipped with a flow cell. Before reading, and after the incubation, the tubes were cooled to $4^{\circ}$. The standards contained $0,0 \cdot 1$, $0.2,0.4,0.6,1 \cdot 0$, and $1.4 \mathrm{ng}$ per $10 \mathrm{ml}$ of medium. It was assumed that optical density was proportional to folate content within this range of concentration (Cooper, 1970), and the mean slope of such a line was calculated after setting the colorimeter to 0 with the standards to which no folic acid had been added. The optical density of all other samples was determined, and for those with optical density within the range of the standards, folate content was calculated directly from the slope of the standard $\frac{0}{5}$ curve using a multiplier control on a digital readout apparatus attached to the colorimeter.

\section{Duration of incubation}

It has been reported that serum folate calculated $\frac{\bar{C}}{\overline{0}}$. from standards of folic acid may be inaccurate if the $\frac{\bar{\sigma}}{\sigma}$ period of incubation is not appropriate (Streeter and $\stackrel{\Phi}{\varrho}$ O'Neill, 1969). We have verified that the serum folate calculated after incubation for 18, 20, and 24-

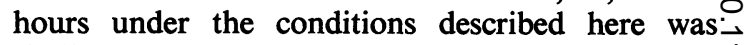
similar, whereas different results were obtained with $\vec{\omega}$ longer and shorter incubations (data not shown) $\frac{\text { ? }}{0}$

\section{Miscellaneous}

Ten ml of haemation shaken with $175 \mathrm{mg}$ of activated charcoal (Norite $\mathrm{A}$ ) for $10 \mathrm{~min}$ at room temperature, centrifuged, and the supernatant assayed for folate. Chromatography ofo folates utilized DEAE Sephadex as described by Nixon and Bertino (1971) eluted with a gradient of $0.8 \mathrm{M}$ potassium phosphate mixing with an equal ${ }_{\varnothing}^{\infty}$ volume of $0.07 \mathrm{M}$ phosphate at $\mathrm{pH} 6.9$. Fifty frac- $\frac{\mathbb{D}}{3}$ tions each of $10 \mathrm{ml}$ were collected at $4^{\circ} \mathrm{C}$ overnight. With this system, authentic 10-formyltetrahydro-folate, 5 -formyltetrahydrofolate, and folic acid eluge $\overrightarrow{0}$ about tubes 17,24 , and 40 respectively.

\section{Results}

COMPARISON OF ASSAY WITH

CHLORAMPHENICOL-ADAPTED AND NORMAL L. CASEI

As indicated in fig 1, growth response of both organisms to folic acid was similar within the range used for ${ }_{\supset}$ the standard curve in our laboratory. The organismo adapted to chloramphenicol sometimes changed its. growth requirements, however, and although itso growth response in the standard curve was appro-

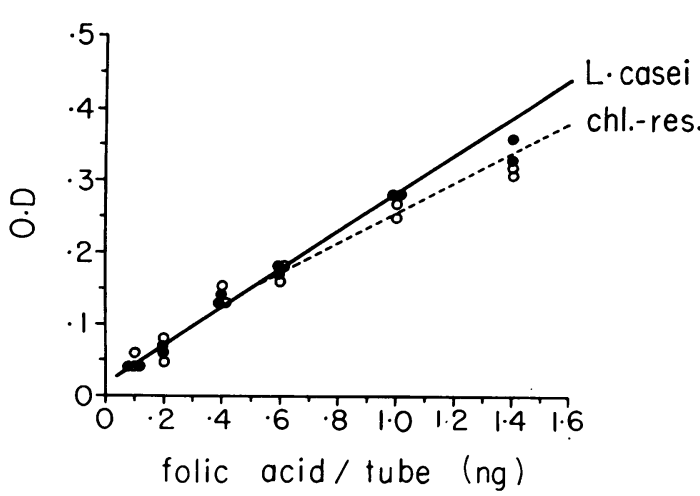

Fig 1 Growth response of routine $\mathrm{L}$. casei, and chloramphenicol-adapted $\mathrm{L}$. casei to folic acid 


\begin{tabular}{lll}
\hline Condition & Heat Extract Assay $(\mathrm{ng} / \mathrm{ml})$ & Chloramphenicol-adapted Assay $(\mathrm{ng} / \mathrm{ml})$ \\
\hline Routine & $12 \cdot 2,12 \cdot 7,13 \cdot 0$ & $19 \cdot 0,19 \cdot 1,20 \cdot 1$ \\
Adsorbed with charcoal & $0 \cdot 5,0 \cdot 7,1 \cdot 0$ & $16 \cdot 0,16 \cdot 1$ \\
Mock charcoal & $13 \cdot 0,13 \cdot 1,13 \cdot 4$ & $19 \cdot 3,20 \cdot 3,20 \cdot 0$ \\
\hline
\end{tabular}

Table Residual 'folate' after adsorption of serum with charcoal, assayed by chloramphenicol-adapted L. casei

priate, the values obtained with serum were abnormally high. To determine if the material supporting excessive growth in serum was folate, aliquots of serum were assayed with both organisms and compared with results obtained after shaking the serum with $100 \mathrm{mg} / \mathrm{ml}$ of activated charcoal, or shaking in the absence of charcoal (see table). It is apparent that whereas charcoal removed most of the folate from serum, significant growth continued with the chloramphenicol-adapted strain during this change in its growth response. This non-folate material was destroyed by heating the serum to $60^{\circ} \mathrm{C}$ for 30 minutes.

To compare the folate assayed in serum by both organisms using heat extraction and direct assay, five sera were assayed simultaneously with both organisms using both direct assay and heat extraction. To prevent artefacts in direct assay with the chloramphenicol-adapted strain, sera for direct assay were first heated to $60^{\circ}$ for $30 \mathrm{~min}$ to destroy the non-folate material sometimes utilized by this strain. The folate concentration in each sample was calculated based on the appropriate standard curve, and the mean values were plotted against serum folate previously assayed routinely by the heat extraction technique using the conventional organism (fig 2). It is apparent that values assayed by all techniques were similar. At times when the chloramphenicol-adapted strain had not altered its growth requirements, such heating was not required. At other times, the chloramphenicoladapted organism failed to grow vigorously in chloramphenicol, requiring subculture in a lower concentration of the drug. These variations in growth were observed with three different shipments of the organism after three to four subcultures. Because of these variations in growth response, we have concluded that the chloramphenicol-adapted organism is too unstable for routine use.

DIRECT ASSAY OF SERUM AND WHOLE

BLOOD USING ROUTINE L. CASEI

The routine strain of $L$. casei grows vigorously and overgrows most contaminants under the conditions of the assay (Herbert, 1966). We attempted to incorporate the simplifications in assay technique developed for the chloramphenicol-adapted strain to routine assay with $L$. casei without chloramphen-

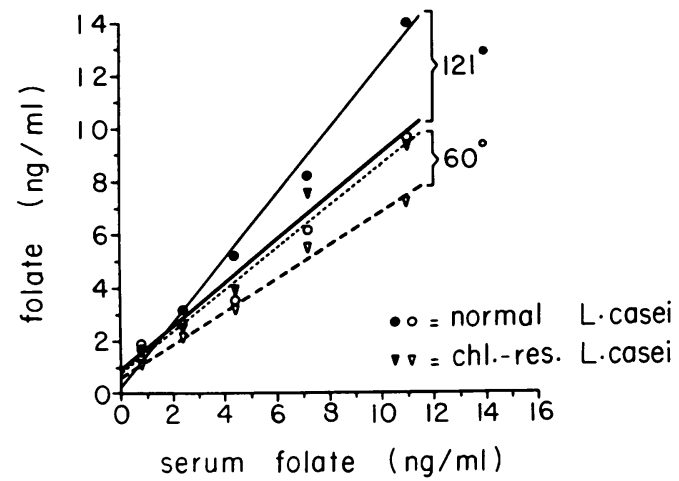

Fig 2 Growth response of $\mathrm{L}$. casei to serum folate. Assay with routine $\mathrm{L}$. casei and chloramphenicoladapted $\mathrm{L}$. casei by direct assay and after heat extraction is compared with serum folate assayed by heat extraction. Serum was heated to $60^{\circ} \mathrm{C}$ for 30 minutes before direct assay.

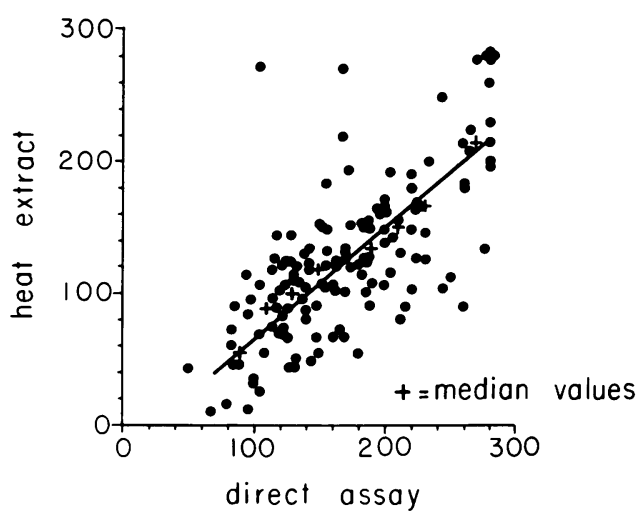

Fig 3 Whole blood folate assayed with routine L. casei. Comparison of direct assay and assay after heat extraction.

icol. As described above, the organism was mixed with diluted medium, and the mixture of medium and organism was pipetted into assay tubes using an automatic pipetting machine. Results obtained for serum folate were almost identical with both techniques. For example, the linear correlation coefficient(r) for 100 sera assayed by both techniques was 0.852 , 
$y=0.028+0.959 x$. Over 2000 samples have been assayed in triplicate with this direct assay technique without autoclaving. None of the tubes have shown detectable contamination with other organisms.

Good correlation also was obtained between whole blood folate assayed by heat extraction, and by direct assay of $0.1 \mathrm{ml}$ of a $1 / 20$ dilution of whole blood in ascorbate water (fig 3) $(r=0.84$, $y=30.5+0.83 x$, where $y=$ direct assay, and $x=$ heat extract assay). It was noted, however, that whole blood folate values were higher by direct assay than after heat extraction.

\section{CHARACTERISTICS OF THE ADDITIONAL 'FOLATE' ACTIVITY IN WHOLE BLOOD BY DIRECT ASSAY}

Monoglutamyl folates are readily adsorbed by activated charcoal. To determine if the additional 'folate' activity increased in whole blood by direct assay was due to folate which might be adsorbed to charcoal, the following experiment was done: 1/20 dilutions of blood in ascorbate-water were incubated with $175 \mathrm{mg}$ of Norite A per $10 \mathrm{ml}$, centrifuged, and the supernatant assayed, both by adding $0.1 \mathrm{ml}$ of the supernatant directly to assay tubes containing medium and organism, and by diluting the supernatant 1:10 in ascorbate-phosphate, autoclaving, and adding $1 \mathrm{ml}$ of the cooled supernatant of the heat extract to similar assay tubes. The optical density of the tubes was plotted and calculated as folate against the standard curve. These 'folate' values were compared with whole blood folate assayed by the extraction technique without charcoal adsorption, with haematocrit, and with the optical density of uninoculated samples with and without charcoal adsorption. Results were as follows.

There was a clear correlation between haematocrit and the 'folate' assayed by direct assay after adsorption with charcoal $(\mathrm{r}=0.643, \mathrm{n}=20, \mathrm{t}=3.568$, $\mathbf{P}<0.001$ ).

No relationship was apparent between haematocrit and whole blood folate $(r=0.298, n=20$, $t=1.325, \quad P>0.2$ ) or haematocrit and 'folate' assayed after charcoal adsorption by the heatextraction technique $(\mathrm{r}=0.358, \mathrm{n}=20, \mathrm{t}=1.634$, $P>0 \cdot 1$ ).

No clear relationship was observed between whole blood folate and the 'folate' assayed after adsorption with charcoal either by direct assay or heat extraction $(\mathrm{r}=0.380, \mathrm{n}=20, \mathrm{t}=1.75$, $\mathrm{P}>0.05$, and $\mathrm{r}=\mathbf{0 . 3 8 5 ,} \mathrm{n}=20, \mathrm{t}=1.776$, $P>0.05$ respectively). These parameters, however, approached significant correlation, and this apparent possible relationship was found not dependent on a small number of extreme values. It is possible that a weak relationship exists between folate assayed in whole blood, and the remaining 'folate' activity $\stackrel{0}{\overrightarrow{5}}$ after adsorption of haemolysates with charcoal.

The optical density of uninoculated tubes corre- $\overrightarrow{\vec{D}}$ lated with haematocrit but did not account for more $\frac{7}{7}$ than $25 \%$ of the 'folate' activity assayed by direct 듬 assay in samples previously adsorbed with charcoal. $\frac{\bar{\omega}}{\bar{\omega}}$. Subtraction of the optical density of the unino- $\vec{\nabla}$ culated tubes from that of the charcoal-adsorbed 2 samples assayed directly, however, abolished the क correlation between haematocrit and the 'folate' $\overrightarrow{0}$ assayed in these tubes $(\mathrm{r}=0.088, \mathrm{n}=9, \mathrm{t}=0.23, \vec{\overrightarrow{ }}$ $P>0 \cdot 8)$. The 'folate' assayed by direct assay after $\vec{\sigma}$ adsorption of haemolysates with charcoal represented a mean of about twice that assayed by heat extraction after charcoal treatment, but the two assays did not $\stackrel{N}{\circ}$ correlate in any single sample.

To determine if the residual 'folate' activity was 8 due to folate, whole blood diluted $1 / 20$ was treated $\mathrm{\omega}$ with charcoal as above, and the supernatant was $ᄋ$ applied to a column of DEAE Sephadex, eluted from the column, and the eluate assayed with L.casei. A small amount of bacterial growth was observed in the $\mathbb{\Phi}_{\overparen{D}}$ assay of the first three or four tubes eluted from the $\frac{1}{3}$ column, corresponding to the position of elution of $\frac{\mathbb{Q}}{-}$ haemoglobin, but to that of none of the known $\overrightarrow{\overrightarrow{0}}$ folates. It was concluded that the apparent 'folate 8 activity assayed was due to the optical density of the haemoglobin and other materials in the haemol产: sate and to a non-folate material. The small amount of apparent 'folate' activity assayed in the heat extract of charcoal-treated haemolysate also eluted $\stackrel{0}{\circ}$ from DEAE Sephadex in the first few tubes, and $\stackrel{\varnothing}{\varnothing}$ apparently represented some non-haemoglobin spur- $\overrightarrow{\overrightarrow{0}}$ ious folate assayed in this system. These studies 3 indicate that a small proportion (about 1/6) of the folate assayed in whole blood after heat extraction, and a larger proportion (about 1/4) assayed by direct assay of the diluted haemolysate, is not due? to known folates.

\section{Discussion}

Thes studies demonstrate that aithough one may assay folate without significant fear of contamination 7 using the $L$. case $i$ adapted to chloramphenicol, in our hands it is too unstable for routine reliable $N_{\mathscr{N}}$ assay. The alteration of its growth requirement to include an apparent non-folate present in serum may make detection of such alteration difficult, since its $\omega$ growth response in tubes containing folic acid alone remains appropriate. It may be more stable on dryo paper discs, but this has not been examined, We have confirmed that the routine strain of $L$. casei grows so ${ }^{+}$ rapidly that contamination in previously sterilized ${ }^{0}$ media is extremely unusual, and indeed has not been

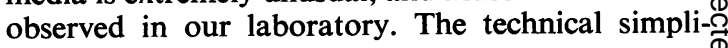


fication of the assay developed for the chloramphenicol-resistant organism thus can be used for the routine organism without the risk of repeated exposure of the technical staff to chloramphenicol. We have confirmed that serum folate assayed by this technique is equivalent to serum folate assayed by heat extraction. Whole blood folate cannot be assayed accurately by direct addition of haemolysate to culture medium, since turbidity and bacterial growth supported by haemolysates was found to be influenced by the number of erythrocytes added as well as their folate content. The evidence that using direct assay, a non-folate material was assayed in addition to folate in the erythrocytes includes its position of elution from DEAE Sephadex, and its failure to adsorb to activated charcoal. One may correct for some of this non-folate activity by subtracting the growth obtained in haemolysates adsorbed with charcoal or uninoculated tubes (Lui, 1973), but this probably would not represent a technical improvement over the method using heat extraction.

Assay of whole blood folate without correction for the optical density due to non-folates may provide an adequate clinical screening technique if haematocrit values do not vary widely, and if normal ranges are determined (Millbank et al, 1970; Chanarin et al, 1972). Although it has been suggested that correction for non-folate optical density may not be required (Millbank et al, 1970), their data include a calculated whole blood folate of 12.648 by direct assay of haemolysate when that by heat extraction was 0 . Because of the variability of the folate assay, and the error introduced into calculation of erythrocyte folate by variations in haematocrit, the small non-folate component measured by this technique may prejudice the reliability of assays of whole blood folate. It is suggested that this technique for whole blood folate assay include standardization of the haematocrit of samples to be assayed, and correction for the optical density due to haemoglobin.

This work was supported by grant MT802 of the Medical Research Council of Canada.

References

Baker, H., Herbert, V., Frank, O., Pasher, I., Hutner, S. H., Wasserman, L. R., and Sobotka, H. (1959). A microbiological method for detecting folic acid deficiency in man. Clin. Chem., $5,275-280$.

Chanarin, I., Kyle, R., and Stacey, J. (1972). Experience with microbiological assay for folate using a chloramphenicol-resistant L. casei strain. J. clin. Path., 25, 1050-1052.

Cooper, B. A. (1970). Studies of $(3 \mathrm{H})$ folic acid uptake by Lactobacillus casei. Biochim. biophys. Acta (Amst.), 208, 99-109.

Davis, R. E., Nicol, .D. J., and Kelly, A. (1970). An automated method for the measurement of folate activity. J. clin. Path., 23, 47-53.

Herbert, V. (1966). Aseptic addition method for Lactobacillus casei assay of folate activity in human serum. J. clin. Path., 19, 12-16.

Kamen, B. A., and Hines, J. D. (1973). Direct radiochemical assay for serum folate: competition between ${ }^{3} \mathrm{H}$-folic acid and 5methyltetrahydrofolic acid. J. Lab. clin. Med., in press.

Liu, Y. K. (1973). Personal communication.

Millbank, L., Davis, R. E., Rawlins, M., and Waters, A. H. (1970). Automation of the assay of folate in serum and whole blood. J. clin. Path., 23, 54-59.

Nixon, P. F., and Bertino, J. R. (1971). Separation and identification of folate coenzymes on DEAE-sephadex. Meth. Enzymol., 18, part B, 661-663.

O'Broin, J. D., Scott, J. M., and Temperley, I. J. (1973). A comparison of serum folate estimations using two different methods. J. clin. Path., 26, 80-81.

Rothenberg, S. P., Da Costa, M., and Rosenberg, A. (1972). A twophase ligand-binding radioassay for serum folate. Clin. Res., 20, 555 .

Streeter, A. M., and O'Neill, B. J. (1969). Effect of incubation time on the $L$. casei bioassay of folic acid in serum. Blood, 34, 216-221.

Waxman, S., Schreiber, C., and Herbert, V. (1971). Radioisotopic assay for measurement of serum folate levels. Blood, 38, 219-228. 